\title{
ANALISIS GEOMETRI ANODA DALAM OPTIMASI DESAIN SUMBER ION PENNING UNTUK SIKLOTRON
}

\author{
Silakhuddin \\ Pusat Teknologi Akselerator dan Proses Bahan, BATAN \\ Jl. Babarsari Kotak Pos 6101 ykbb, Yogyakarta 55281
}

Diterima 08 April 2008, diterima dalam bentuk perbaikan 08 Juni 2009, disetujui 15 Juni 2009

\section{ABSTRAK}

\begin{abstract}
ANALSIS GEOMEIRI ANODA DALAM OPTIMASI DESAIN SUMBER ION PENMNG UNTUK SIKLOTRON. Dalam mempersiapkan desain detil dari sumber ion jenis Penning untuk siklotron produksi radioisotop PET, telah dilakukan analisis terhadap tiga bentuk geometri dari anoda sumber ion tersebut. Analisisnya menggunakan program Poisson Superfish untuk menentukan geometri anoda yang optimum. Tiga bentuk geometri dari dinding dalam anoda yaitu: lurus, menyempit ke tengah dan menyempit di tengah telah dianalisis dan dibandingkan. Hasil dari analisis menunjukkan bahwa bentuk geometri menyempit di tengah merupakan bentuk yang diprediksikan mempunyai intensitas plasma di daerah ekstraksi yang paling kuat. Efek adanya lobang ekstraksi menunjukkan pengurangan intensitas plasma di daerah tersebut.
\end{abstract}

Kata kunci: sumber ion Penning, siklotron, anoda

\begin{abstract}
ANALYSIS OF ANODE GEOMEIRY ON DESIGN OPTMIING OF PENMING ION SOURCE FOR CYCLOTRON. To prepare a detail design of the Penning ion source of the cyclotron for PET radioisotope production, the anode geometri shapes of ion source have been analyzed. The Poisson-Superfish computer code has been used in the analysis to determine an optimum design of the anode. Three geometry shapes of anode inner wall namely: stright, narrows to center and narrows on center have been analyzed and compared each other. The result of analysis shows that the anode geometry which narrows in center is predicted will has a strongest plasma intensity in the extraction region. The presence of an extraction hole will decrease intensity plasma on this region.
\end{abstract}

Keywords: Penning ion sorce, cyclotron, anode

\section{PENDAHULUAN}

Dalam jangka waktu 6 tahun ke depan di PTAPB-BATAN Yogyakarta dicanangkan program desain sistem siklotron untuk produksi radioisotop PET. Tujuan utama kegiatan ini adalah untuk memperoleh kemampuan teknologi desain sistem siklotron untuk mengantisipasi kecenderungan meningkatnya instalasi siklotron produksi radioisotop PET pada beberapa rumah sakit di Indonesia.

Desain komponen sumber ion siklotron berinduk pada program desain sistem siklotron, yang pada tahun pertama ini (2009) dimulai dengan program kajian. Kajiannya tidak bermula dari dasar melainkan mengacu pada desain-desain yang sudah ada. Walau desain dari fasilitas tersebut memang sudah terbukti operasi, namun desain yang ada pada siklotron-siklotron produksi PET (khususnya yang ada dan yang akan ada di Indonesia) mungkin akan berbeda. Untuk itu perlu ada wawasan dan penguasaan dalam pendalaman desain dari sumber-sumber ion yang digunakan dalam siklotron, sehingga akan memberikan kemudahan dalam memahami desain-desain yang berbeda. Dampak lebih lanjut dari pemahaman desain sumber ion adalah dimungkinkan diperolehnya kemampuan dalam rekayasanya.

Jenis sumber ion yang umumnya dipakai pada siklotron adalah jenis Penning, karena sumber ion ini medan magnet yang diperlukan untuk meningkatkan intensitas ionisasinya dapat memanfaatkan medan magnet siklotron itu sendiri. Dalam sistem sumber ion ini anoda merupakan komponen yang relatif sering diganti setelah katoda. Geometri katoda sangat sederhana sehingga tidak perlu dilakukan studi desainnya, sedangkan anoda mempunyai geometri yang spesifik karena di tempat inilah terjadinya ionisasi dalam pembentukan berkas ion. 
Pada makalah ini akan disajikan hasil-hasil penelaahan menggunakan program komputer Poisson Superfish dengan memilih beberapa geometri anoda sumber ion. Kriteria optimasinya didasarkan pada medan elektrostatik yang paling besar kemungkinannya membentuk plasma di sekitar lobang ekstraksi. Karena pembentukan plasma dalam sumber ion Penning ini akibat tumbukan elektron maka akan disajikan terlebih dahulu tentang teori gerakan elektron di dalam sumber ion jenis Penning. Hasil-hasil optimasi ini akan dapat dimanfaatkan sebagai bahan untuk proses desain keteknikan.

\section{TEORI OPERASI SUMBER ION JENIS PENNING DALAM SIKLOTRON}

Sumber ion jenis Penning atau biasa disingkat PIG (singkatan dari Penning lonization Gauge) lazim digunakan sebagai sumber ion yang dipasang secara internal dalam siklotron yang mempercepat ion dari sedikit jenis ion, misalnya hanya ion-ion hidrogen. Ionisasi atom atau molekul gas di dalam sumber ion Penning adalah akibat dari tumbukan elektron (berasal dari katoda) yang bergerak bolak-balik di dalam ruang lucutan yang juga rongga anoda. Intensitas ionisasi diperbesar dengan gerakan spiral karena adanya medan magnet siklotron yang mengarah secara aksial (Gambar 1).

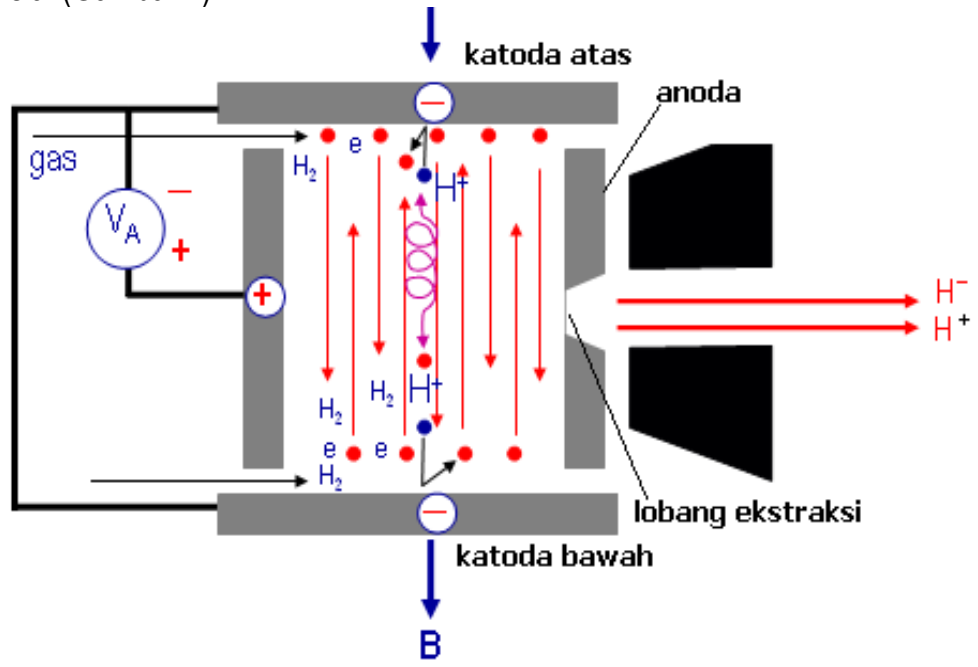

Gambar 1. Skema prinsip sumber ion jenis Penning

Faktor-faktor yang mempengaruhi intensitas ionisasi $I_{i}$ antara lain adalah arus elektron $l_{e}$, volume efektif ruang ionisasi $V$, kerapatan atom atau molekul $n_{a}$ dan tampang lintang ionisasi oleh elektron $\sigma_{i}$. Relasi dari besaran-besaran tersebut dinyatakan sebagai $(1)$ :

$$
l_{i}=l_{e} V n_{a} \sigma_{i}
$$

$l_{e}$ ditentukan oleh arus pemanasan katoda, $V$ ditentukan oleh geometri rongga anoda dan ukuran lobang ekstraksi, $n_{a}$ dipengaruhi oleh laju alir gas dan $\sigma_{i}$ sebagai fungsi energi elektron. Pola distribusi medan listrik di dalam rongga anoda akan memberikan pola distribusi energi elektron pengionisasi di dalam rongga tersebut. Pola medan listrik yang terdistribusi lebih kuat pada bagian pusat anoda akan memperbesar ekstraksi berkas keluar.

Konsentrasi elektron dan ion dapat dinaikkan dengan hadirnya medan magnet karena lintasan elektron di dalam ruang lucutan diperpanjang dan kehilangan partikel bermuatan dapat diminimalkan dengan adanya medan magnet. Lintasan elektron secara nyata menjadi lebih panjang karena lintasan spiral di antara dua katoda dan kehilangan partikel bermuatan berkurang sebagian karena efek kolimasi dari medan listrik dan sebagian karena laju difusi ke arah dinding tabung anoda dapat diturunkan. Radius gerakan elektron $r_{e}$ dengan massa $m_{e}$ dan energi eU dalam medan magnet aksial $B_{y}$ dinyatakan sebagai:

$$
r_{e}=\frac{1}{B} \sqrt{\frac{2 m_{e} U}{e}}
$$


Sehingga dengan adanya medan magnet dapat memberikan nilai tambah yang mana daerah lucutan yang kuat dengan konsentrasi elektron dan ion yang tinggi dapat dikonsentrasikan pada kolom yang sempit dengan radius $\sim r_{e}$ di sekitar sumbu lucutan. Energi elektron $U$ terdiri atas komponen $U_{x}$ yang mempengaruhi $r_{e}$ dan komponen $U_{y}$ yang menentukan kekuatan terobosan elektron ke pusat rongga anoda.

Berdasarkan uraian atas persamaan 1 dan 2 di atas diperoleh suatu rumusan bahwa geometri dari anoda akan mempengaruhi pola distribusi medan listrik yang akan menentukan posisi pembentukan plasma terkonsentrasi pada pusat anoda dan menentukan intensitas plasma karena gerakan spiral dari elektron.

\section{METODOLOGI}

\section{Obyek Analisis}

Akan dianalisis dua bentuk anoda yaitu bentuk lurus, bentuk yang menyempit ke tengah dan menyempit di tengah. Acuan bentuk lurus diambil dari desain yang dikemukakan oleh J.S. Chai dkk dari the Korea Cancer Center Hospital (KCCH) seperti disajikan pada Gambar 2a.(2) Acuan kedua diambil penyajian D. Schlyer pada BATAN Accelerator School 2008, seperti disajikan pada Gambar 2b. (3) Gambar 2c adalah desain pada fasilitas Cyclotron 42 di AECL Canada dan KFK Jerman.

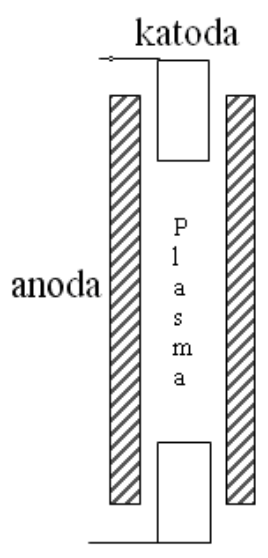

(a)

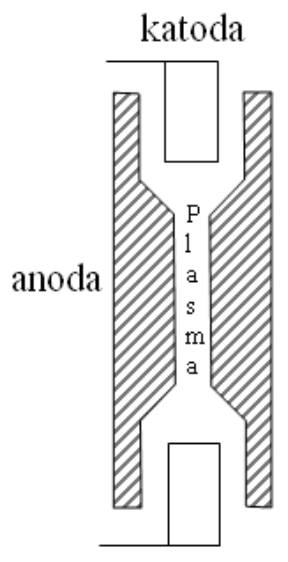

(b)

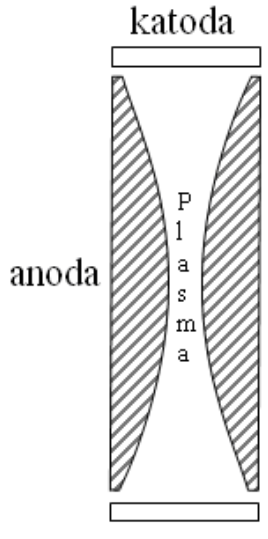

(c)

Gambar 2.. Bentuk-bentuk model geometeri anoda-katoda: (a) desain di $\mathrm{KCCH}$, (b) desain dikemukakan oleh Schlyer dan (c) desain di KFK dan AECL Vancouver

Tidak didapatkan informasi dari ketiga model tersebut tentang kemampuannya dalam menghasilkan arus berkas ion, selain hanya arus berkas dari siklotronnya. Tiga model tersebut akan dianalisis dan untuk penyederhanaan posisi katoda tidak masuk ke dalam rongga anoda hal ini karena akan menyulitkan rancangbangun yang nantinya akan dilakukan. Dari bentuk-bentuk anoda tersebut masing-masing akan dilakukan analisis kualitatif dari pola medan listrik yang terjadi di antara katoda-anoda dan analisis kuantitatif dari besarnya medan listrik di dalam ruang lucutan.

\section{Alat Analisis}

Data yang digunakan untuk analisis diambil dari hasil eksekusi program Poisson-Superfish. Untuk menggunakan program ini diperlukan input file yang mengandung batasan jenis material dan geometri sistem yang diamati (dalam hal ini katoda dan anoda). Hasil dari running program dilihat pada output file. Penjelasan tentang pembuatan input file, running program dan penampilan output file ditunjukkan pada lampiran. Dua keluaran yang diperoleh dari hasil eksekusi program tersebut akan dipakai untuk analisis. Keluaran pertama berupa pola distribusi fluksi medan listrik di antara katoda-anoda, yang dapat dipakai untuk memperbandingkan secara kualitatif dari ketiga bentuk obyek. Dalam penelitian ini tegangan anoda $3000 \mathrm{~V}$ terhadap katoda. Keluaran kedua berupa 
data secara kuantitatif tentang besarnya medan listrik pada daerah yang diamati, dalam penelitian ini diambil sepanjang garis pada sumbu tegak anoda mulai dari titik tengah katoda bawah hingga pusat rongga anoda.

\section{Kriteria Penentuan Desain}

Kriteria optimasi secara kualitatif didasarkan pada posisi yang diprediksikan terbentuknya plasma dengan melihat pola-pola medan listrik di dalam ruang lucutan. Secara kualitatif bentuk-bentuk geometri anoda akan dibandingkan dengan melihat pola-pola distribusi fluksi medan listriknya. Pola yang memperlihatkan adanya komponen $E_{x}$ dan $E_{y}$ di daerah yang lebih ke pusat anoda dianggap yang lebih baik. Secara kuantitatif akan dilihat distribusi E sepanjang garis sumbu y. Geometri anoda yang menghasilkan distribusi $E_{y}$ lebih besar di bagian pusat (atau lebih dekat pusat) menjadi pilihan desain.

Akhirnya setelah diperoleh pilihan geometeri anoda yang optimal maka akan dilihat juga efek dari adanya lobang ekstraksi berkas ion pada dinding anoda terhadap pola medan listrik, karena adanya lobang tersebut akan mengurangi intensitas berkas ion ${ }^{[3]}$.

\section{HASIL DAN PEMBAHASAN}

Hasil running program Poisson Superfish ditunjukkan pada Gambar 3 hingga Gambar 7. Gambar-gambar tersebut memperlihatkan garis-garis ekuipotensial yang ditimbulkan karena adanya beda potensial anoda $\mathrm{V}_{\mathrm{a}}=+3000 \mathrm{~V}$ terhadap katoda. Arah vektor medan listrik pada titik di suatu garis adalah tegak lurus terhadap garis tersebut dan mengarah dari anoda ke katoda. Kerapatan dari garis-garis ekuipotensial di suatu tempat menunjukkan besarnya fluksi medan listrik di tempat tersebut. Posisi $\mathrm{x}=0 \mathrm{~cm}$ adalah pada batas dinding anoda kiri dan $\mathrm{y}=0 \mathrm{~cm}$ adalah batas tepi katoda bagian bawah. Pusat rongga anoda pada $\mathrm{x}=1 \mathrm{~cm}$ dan $\mathrm{y}$ $=3 \mathrm{~cm}$. Pada Gambar-gambar 3 dan 5 ditunjukkan pola distribusi medan magnet di dalam rongga anoda, yang secara kualitatif dapat untuk membandingkan tentang seberapa jauh medan listrik yang dibangkitkan dapat masuk ke pusat rongga anoda. Untuk melihat perbandingan secara kuantitatif dipakai Gambar-gambar 4 dan 6 yang menunjukkan besarnya vektor medan listrik pada garis $x=1 \mathrm{~cm}$ dan $y=0 \mathrm{~cm}$ hingga $y=3 \mathrm{~cm}$.

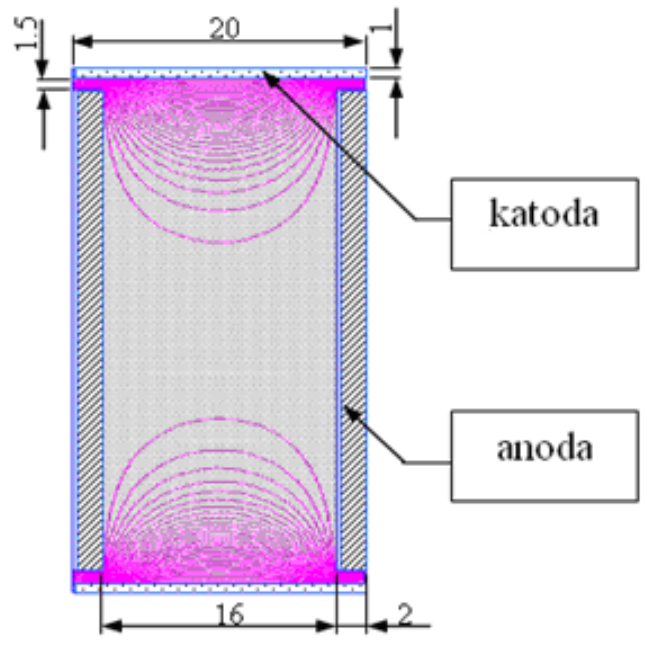

(3a)

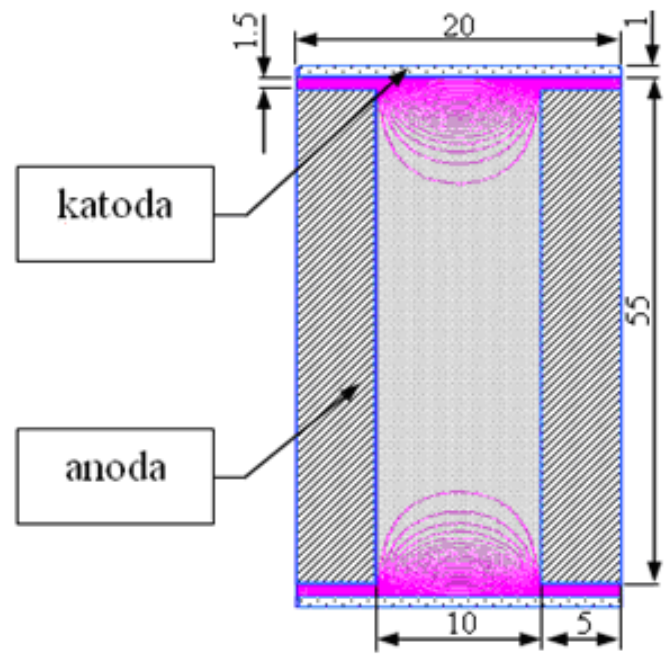

(3b)

Gambar 3. Distribusi fluksi medan listrik untuk anoda-anoda lurus, di mana (3a) untuk anoda rongga besar dan (3b) untuk anoda rongga kecil 


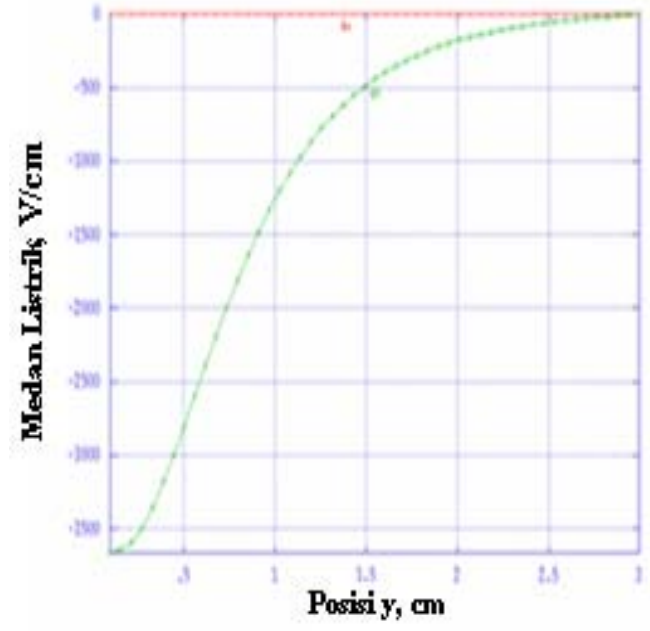

(4a)

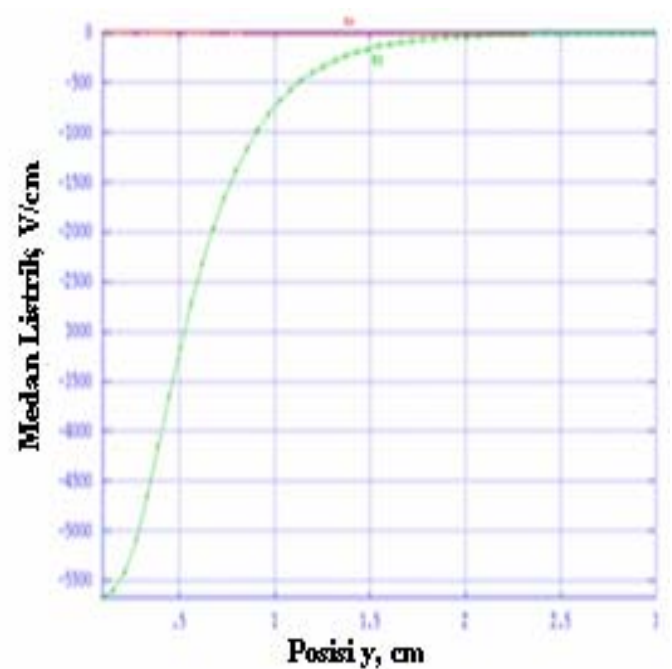

(4b)

Gambar 4. Distribusi kuantitatif medan listrik untuk anoda-anoda lurus berongga besar (a) dan berongga kecil (b), pada posisi garis $x=1 \mathrm{~cm}$ dan $y=0 \mathrm{~cm}$ hingga $y=3 \mathrm{~cm}$

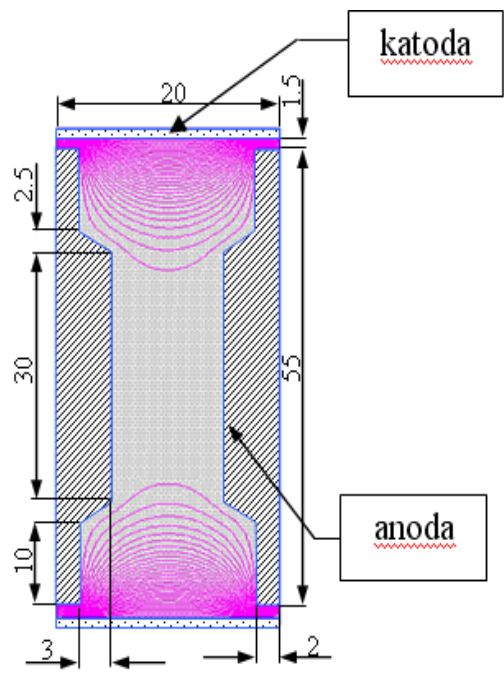

(5a)

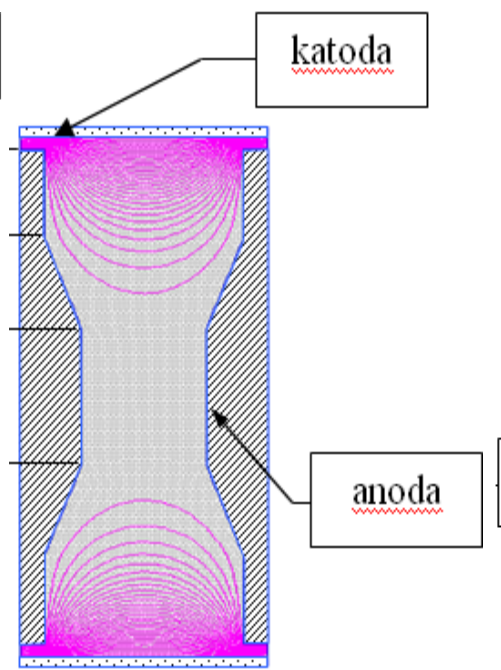

$(5 b)$

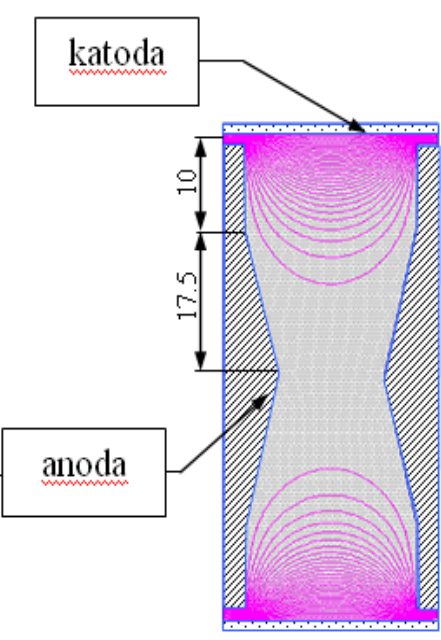

(5c)

Gambar 5. Distribusi fluksi medan listrik untuk anoda anoda menyempit. Gambar (5a) dan (5b) adalah bentuk menyempit ke tengah dan Gambar $(5 c)$ adalah bentuk menyempit di tengah 


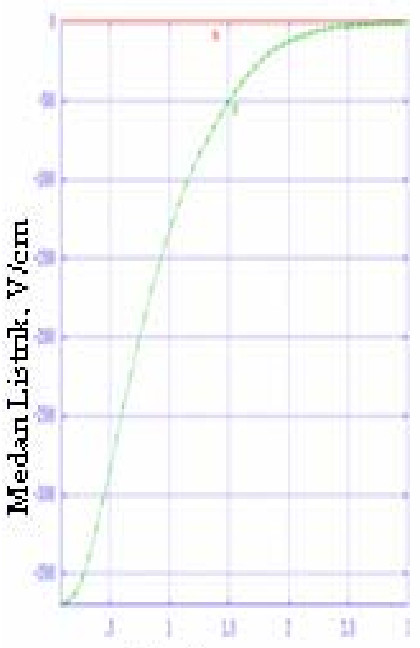

Posisi $y, a m$

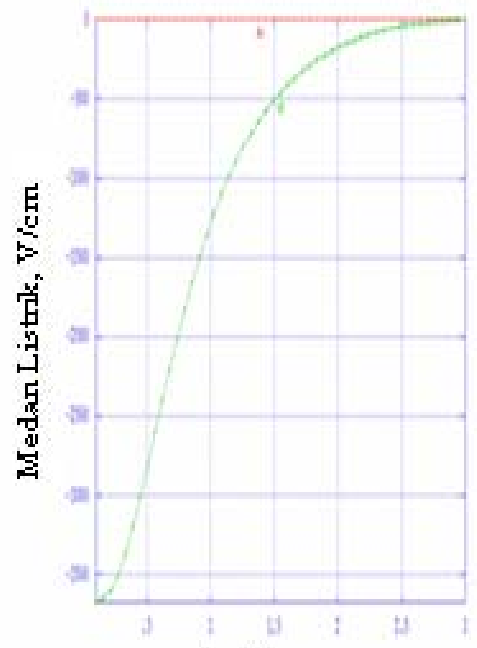

Posisi $y, a m$

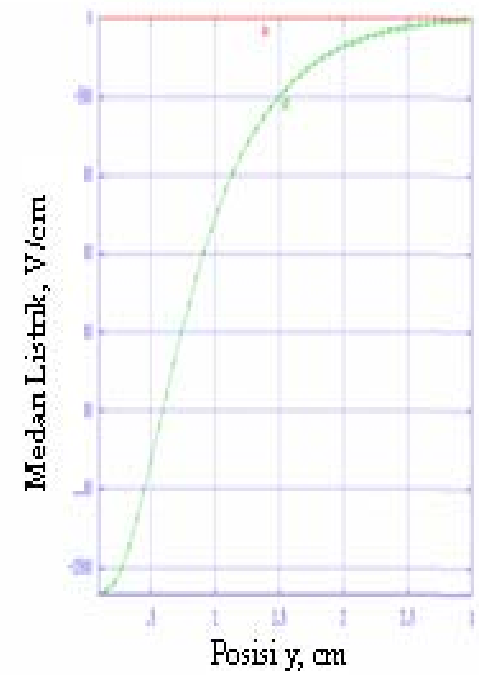

(6c)

(6a)

(6b)

Gambar 6. Distribusi kuantitatif medan listrik untuk bentuk-bentuk anoda seperti pada Gambar 5 , pada posisi garis $x=1 \mathrm{~cm}$ dan $y=0 \mathrm{~cm}$ hingga $y=3 \mathrm{~cm}$

Secara umum untuk semua bentuk anoda terlihat bahwa medan listrik sangat kuat pada ujung-ujung anoda. Untuk mencegah adanya lucutan corona (corona discharge) atau bahkan lucutan percikan (spark discharge) maka harus dihindari bentuk yang runcing pada ujung anoda ini.

Apa yang ditunjukkan pada desain anoda dengan rongga anoda lurus (Gambar 3a dan Gambar 3b) menunjukkan bahwa anoda dengan ruang ionisasi yang lebih besar ternyata menghasilkan fluksi medan listrik (E) yang lebih masuk ke bagian tengah, yang berarti terjadi pembentukan ionisasi yang kuat di daerah ekstraksi. Perbandingan secara kuantitatif tampak nyata jika membandingkan antara Gambar 4a dengan Gambar 4b, misalnya pada Gambar 4a medan listrik mendekati nol setelah $y=2,5 \mathrm{~cm}$ sedangkan pada Gambar $4 \mathrm{~b}$ hal terjadi sebelum $\mathrm{y}=2 \mathrm{~cm}$.

Jika melihat pola fluksi medan listrik pada Gambar-gambar $5 a, 5 b$ dan $5 c$, bentuk-bentuk anoda dengan rongga menyempit maka variasi $\mathrm{E}$ secara kasar tidak jauh berbeda, demikian juga dengan bentuk anoda lurus berongga besar seperti Gambar 3a. Tetapi pengamatan secara cermat pada Gambar 6a, 6b dan 6c menunjukkan bahwa semakin runcing ujung penyempitan maka distribusi fluksi medan listrik semakin ke dalam. Sebagai contoh pada posisi $y=2,5 \mathrm{~cm}$, nilai E pada Gambar $6 a$ dan $6 \mathrm{~b}$ sudah sangat mendekati nol tetapi tidak demikian pada Gambar 6c. Jadi dapat dikatakan bahwa desain dengan penyempitan rongga di tengah (di sekitar pusat rongga) merupakan desain yang relatif lebih besar untuk menghasilkan konsentrasi ionisasi di pusat rongga anoda. Secara teori diprediksikan bahwa desain terakhir ini akan menghasilkan berkas ion terekstraksi yang juga lebih besar. Dengan mengambil geometri terpilih seperti Gambar 5c, selanjutnya dilihat efek dari lobang ekstraksi terhadap pola medan listrik di dalamnya. Hasil running program Poisson-Superfish ditunjukkan pada Gambar 7.

Jika hanya ditinjau di bagian rongga anoda, adanya lobang ekstraksi akan menimbulkan medan listrik yang positif (ke arah atas) di bagian pusat, ini terlihat pada Gambar $7 \mathrm{~b}$ di mana mulai kira-kira y =2,3 m medan listriknya sudah positif. Kondisi ini akan menghambat gerakan elektron sewaktu menuju ke pusat anoda. Pengurangan gerakan elektron di sekitar lobang ekstraksi akan mengurangi intensitas plasma di tempat tersebut. Dapat diprediksi bahwa semakin sempit lobang ekstraksi akan memperbesar intensitas plasma. Akan tetapi lobang ekstraksi yang sempit juga mengurangi volume efektif ionisasi seperti disebutkan pada persamaan (1). Jadi diperlukan suatu penelitian lanjutan untuk mencari optimasi mengenai ukuran dari lobang ekstraksi. 


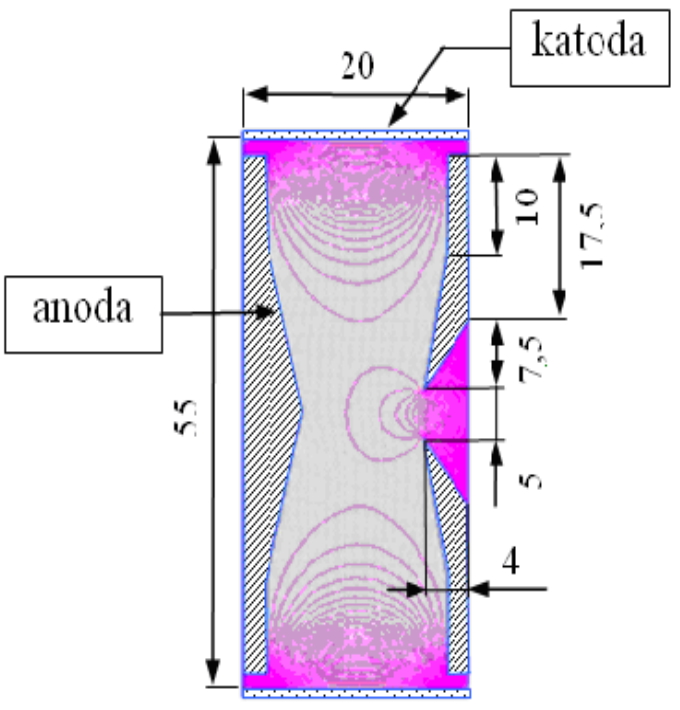

(a)

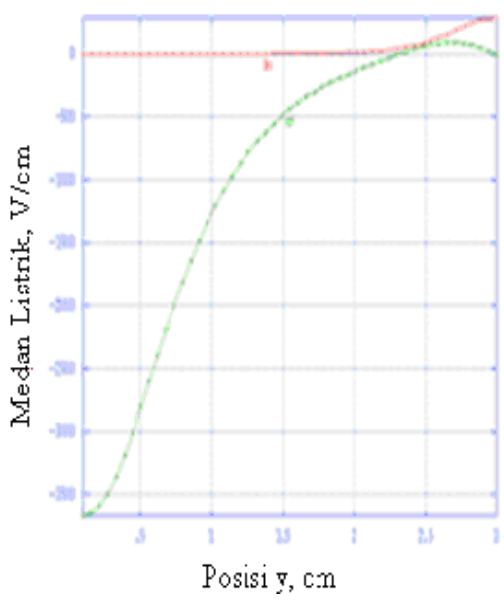

(b)

Gambar 7. (a).Distribusi fluksi medan listrik untuk anoda menyempit di tengah dan berlobang ekstraksi

(b). Distribusi kuantitatif medan listriknya

\section{KESIMPULAN DAN SARAN}

Telah dilakukan pengamatan terhadap 3 bentuk geometri dari anoda sumber ion jenis Penning yang dipakai untuk siklotron khususnya yang dipasang secara internal di dalam daerah pusat (central region) siklotron. Tiga bentuk yang diperbandingkan adalah anoda berdinding dalam: lurus, menyempit ke tengah dan menyempit di tengah. Hasil analisis secara kualitatif dan kuantitatif menggunakan program Poisson-Superfish menunjukkan bahwa geometri anoda yang menyempit di tengah diprediksikan akan menghasilkan intensitas plasma di bagian tengah yang paling kuat atau menghasilkan berkas ekstraksi yang paling besar. Efek adanya lobang ekstraksi diprediksikan akan mengurangi intensitas plasma di bagian tengah. Tetapi karena lobang ekstraksi yang kecil juga mengurangi permukaan ekstraksi, maka diperlukan penelitian lanjutan untuk menentukan ukuran yang optimum dari lobang ekstraksi dalam menghasilkan arus berkas terekstraksi yang besar.

\section{UCAPAN TERIMA KASIH}

Ucapan terima kasih disampaikan kepada saudara Gustus Tricahyo dan saudara Taufik Penta Bahari yang telah membantu dalam menyempurnakan gambar-gambar.

\section{DAFTAR PUSTAKA}

1. L. VALYI, Atom and Ion Sources, John Wiley \& Sons, New York, (1977).

2. J.S. CHAl, "New Design and Development of 13 MeV PET Cyclotron in Korea", Proceedings of the 1999 Particle Accelerator Conference, New York, (1999).

3. D. SCHLYER,"lon Sources", Bahan Kuliah pada BATAN Accelerator School, PTAPB-BATAN, (2008). 


\section{LAMPIRAN: PEMBUATAN INPUT FILE, RUNNNG PROGRAM DAN PENAMPILAN OUTPUT FILE}

\section{Pembuatan Input File}

Ada 2 input file yang disiapkan yaitu Plate.am dan Plate.IN7. Di dalam file pertama ditetapkan batasan-batasan geometri dari komponen, jenis material dan tegangan listrik dari komponen (katoda dan anoda). Dalam file kedua ditentukan posisi-posisi di mana hendak dilihat nilai-nilai medan listrik dan potensialnya. Dalam penelitian ini diambil sepanjang garis pada sumbu tegak anoda mulai dari titik tengah katoda bawah hingga pusat rongga anoda. Posisi ini diambil dengan asumsi bahwa garis tersebut merupakan daerah pembentukan plasma yang significant untuk ekstraksi. Secara numerik koordinat posisi garis pertama adalah di antara $x=5 \mathrm{~cm}$ hingga $x$ $=10 \mathrm{~cm}$ dan $y=7 \mathrm{~cm}$, selanjutnya garis ini disebut garis pengamatan.

\section{Running Program dan Output File}

Selesai pembuatan file input dilakukan running program dengan RUNPLATE.BAT, Hasilnya ditampilkan dalam file PLATE.T35 yang menampilkan pola-pola garis ekuipotensial di antara katoda dan anoda. Besaran numerik dari medan listrik dan potensial di semua titik dapat terbaca dengan menggerakkan cursor dan ditampilkan pada window yang disebut "cursor location and field." Output file lainnya adalah OUTSFT7.TXT yang menyajikan data numerik dari medan listrik dan potensial sepanjang garis pengamatan yang sudah ditentukan oleh input file Plate.IN7. 